Biljana Petrevska ${ }^{1}$

Faculty of Tourism and Business Logistics,

"Goce Delcev" University - Stip, Macedonia

Marija Ackovska ${ }^{2}$

Institute of Economics, "Ss. Cyril and Methodius"

University - Skopje, Macedonia
SCIENTIFIC REVIEW ARTICLE

doi:10.5937/ekonomika1503073P

Received: June 1, 2015

Accepted: July 5, 2015

\title{
TOURISM DEVELOPMENT IN MACEDONIA: EVALUATION OF THE WINE ROUTE REGION
}

\begin{abstract}
The paper evaluates the current status of tourism development in the Wine route region in Macedonia. It analyses the major problems and obstacles that prevent further tourism expansion of this region by pointing to weaknesses that need to be addressed. The main accent is put on the necessity for reformulating the strategy for change. A field survey was conducted in the line of assessing the up-to-date tourism growth. The overall conclusion is that the destination has profound limiting factors for further tourism development. Therefore, the current marketing strategy needs an improvement in the line to overcome the spotted obstacles for destination and product development.
\end{abstract}

Key words: Tourism development, Tourism planning, Wine route, Macedonia

JEL classification: F63, L83, O21

\section{РАЗВОЈ ТУРИЗМА У МАКЕДОНИЈИ: ОЦЕНА РЕГИОНАЛНОГ ВИНСКОГ ПУТА}

\begin{abstract}
Апстракт
У раду се оцењује тренутни статус развоја туризма у региону винског пута у Македонији. Анализирају се главни проблеми и препреке које спречавају даље туристичко ширење овог региона указујући на слабости које се морају решавати. Главни акиенат је стављен на неопхоност да се промени стратегија. Истраживачко поље је спроведено унизу процена раста туризма. Општи закључак је да ова дестинаџија има дубоки ограничавајући фактор за даљи развој туризма. Дакле, садашьу маркетиншку стратегију треба побољшати у правиу превазилажења препрека за поменуту дестинацију и развој производа у њој.
\end{abstract}

Кључне речи: Развој туризма, планирање туризма, вински пут, Македонија

\footnotetext{
${ }^{1}$ biljana.petrevska@ugd.edu.mk

2 marija@ek-inst.ukim.edu.mk
} 


\section{Introduction}

Tourism is one of the most important socio-economic activities related to development at local, regional, national and global level. Although it is treated as a relatively new phenomenon that achieved its boom during the last century, it is noticeable that tourism takes an important part in almost every country where natural, cultural, economic, social and environmental recourses are identified as potentials that may contribute to national economy through tourism development. The importance of tourism is even more evident if it is considered as a part of a worldwide process of globalization. Thus, every country pays certain attention to conditions that contribute to tourism development and its benefits.

Tourism in Macedonia emerged as a major component for regional and overall economic development, which can trigger growth and prosperity. The objective of this paper is to evaluate current stage of tourism development of the Wine route region in Macedonia. In particular, the paper attempts to explore and identify the major problems and weaknesses that need to be addressed. The focus is put on the major opportunities for improvements, particularly formulating the sector vision of change and the vision of change for products and services, as well as the identified interventions to reach the vision of change. The paper is structured in several parts. After the introductory part, Section 2 provides a brief overview on literature addressing the issue of tourism, regional development and tourism destination competitiveness. Section 3 provides some stylized facts for the Wine region, by elaborating the regional and local context. Section 4 presents tourism market map, while Section 5 encompasses the analysis, results and discussion of the research. Future challenges and recommendations are presented in the final section.

The general contribution of the study lies in the fact that enriches poorly developed academic work in this issue related to tourism development of Macedonia. Yet, some exceptions are noted in the work of Petrevska and Nestoroska (2015), Dimoska and Petrevska (2012), Petrevska and Manasieva Gerasimova (2012) as well as Petrevska (2012).

\section{Literature review}

The concept of regional development includes on one hand, the dynamics of development of specific areas, primarily understood as a regional economic development of those areas, but also regional traffic, population or environmental development. There is a large body of literature which main thesis are that regional development must be based on the exploitation of best potentials of the regions environmental features, and sustainable development must be based on reasonable regional development.

In this respect, the conventional thinking about the relationship between tourism and regional development is present in many studies (Sharpley \& Telfer, 2002; Rayan, 2010; Stabler et al, 2010). Other researchers investigate the local, place-based factors that influence tourism development, and ask why some tourism areas develop more than others (Raina \& Agarwal, 2004). Likewise, a focus is put specifically on the less developed world and by arising many assumptions about the role of tourism in development and, in particular, highlighting the dilemmas faced by destinations seeking to achieve development through tourism (Huybers, 2007; Telfer \& Sharpley, 2008). Some authors even endeavor to a critical 
approach within a multi-disciplinary framework to relook at the complex phenomenon of tourism development (Babu et al, 2008; Ramos \& Jimènez, 2008).

Tourism is seen as a 'sunrise' industry that is labor intensive and therefore offers the potential to be a substantial source of employment. In short, much attention has been directed to tourism's economic potential. Due to the relationship between food and tourism, some authors underscore the significant opportunity for product development as a means to rural diversification (Bessière, 1998). Others examine the contemporary issues and reasons for tourism development as a strategy for urban revitalization (Pearce \& Butler, 2002) as well as for providing the basis for a better informed integration of tourism in regional development strategies (Sharma, 2004). Moreover, some discussions are towards various policy innovations as activities by regions in terms of tourism development considering continuous growth within the sector (Giaoutzi \& Nijkamp, 2006). Additionally, as tourism and regional development are closely linked, regions and local authorities play a key role in the formulation of policy and the organization and development of tourism (Constantin, 2000).

Identification of tourism potentials is in close relation with the need of achieving destination competitiveness on tourist market. Many debates are undertaken about the question of tourism development and competitiveness (Kozak \& Remmington, 1999; Maliàn-Gonzàlez \& Garzìa-Falcòn, 2003; Enright \& Newton, 2004; Johns \& Mattsson, 2005; d'Hauteserre, 2000). In this line, Ul Haque (1995) and Barbosa (2008) state that the international debate has been centered on two questions: whether a country's competitiveness has clear meaning, and whether anything can or should be done about it. In addition, identification of tourism potentials and assessment of competitiveness in tourism sector is more complicated due to the heterogeneous character of tourism. Crouch and Ritchie (1999) underlined that it occurs because of the analysts' perspective and focus of their interest, which is related to their respective areas of operation. Furthermore, Dwyer and Kim (2003) argue that every destination must ensure that its general attractiveness and total experiences provided to the visitors are similar or greater than what is offered by other destination. In this light, Gooroochurn and Sugiyarto (2004) state that tourism destination competitiveness is very important for creating sound tourism development policy.

\section{Snapshot on the Wine route region}

The wine tourism in Macedonia is relatively new type of tourism, which is identified in strategic documents (up-date of the National Strategy for Tourism Development 20112015) as separate cluster for regional tourism development. The reasons for such a delay, lays in the fact that the wine was not observed as a possibility for economic development in terms of application as material and spiritual cultural heritage. Side by side with France, Italy and Spain, Macedonia belongs to the so called "old wine countries".

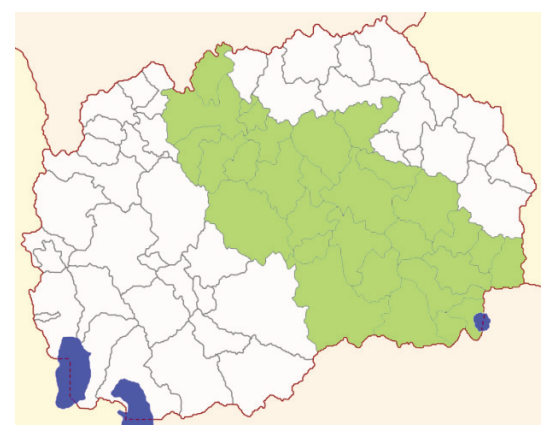

Figure 1. Wine route 
The "wine tourist product" is generally offered to tourists as part of some other tourism supply, or as a day excursion. The offer consists of tasting different wines, tours in the production area, some history lessons, stories, as well as good traditional catering and shopping possibilities. Some of the wineries have accommodation facilities and some offer just catering and wine testing. The most visitor traffic is generated directly, rather than through travel agencies and tour operators. There is a need for more aggressive promotion of the wine tourism product. The wineries are dispersed in three main regions: (1) Povardarie - Vardar Valley (central region); (2) Pcinja - Osogovo (east region); and (3) Pelagonisko Poloski (west region).

Povardarie is the largest and the most famous vineyard region in Macedonia. The geographical representation of the wineries is identical to the representation of the vineyards, where most companies are located in the central region of the Vardar Valley. Hence, the potentials for development of wine tourism are within Povardarie. The destination covers $16 \%$ of the national territory spreading over generally rural municipalities. The population density is very low being only 38 inhabitants $/ \mathrm{km}^{2}$. The general unemployment rate is $43.9 \%$ (higher than the national rate of $29 \%$ ), while the unemployment in services is $47 \%$. The positive light can be seen in the willingness to start own businesses due to governmental activities and support. Yet, the absence of foreign language proficiency is an obstacle for further tourism development. The climate is favorable for development of agriculture, especially viticulture. The destination is reachable by road (909 km of local roads, $56.5 \mathrm{~km}$ of highway, $60.5 \mathrm{~km}$ of main roads and $557 \mathrm{~km}$ of regional roads), train (total length of the railway network is 183.5 $\mathrm{km}$ ) or by nearby national airport in Skopje.

During the past, the vast majority of the wineries produced wine that was sold as bulk without any efforts to build a brand out of the Macedonian wine. The production of the bottled wine was marginalized. Nowadays, the wineries are investing in equipment upgrade, reconstruction and human resource development as the Macedonian wine industry makes the switch from bulk to bottled wine production. They are investing all aspects of the marketing mix and cooperate with the central government in the line of promoting Macedonian wine. Yet, despite the significant improvements, there is still much to do.

\section{Tourism market overview of the Wine route}

Like many countries, Macedonia has been affected by growing regional inequalities during transition. Although regional policies have been put in place over the years and a process of decentralization has been applied since the end of the 2001 conflict, they have as yet not addressed these fundamental inequalities. Officially, in accordance to NUTS3 statistical classification, eight planning regions have been defined, each with own specific characteristics and development problems. In that line, the Law on Equal Regional Development set in 2007, laid the foundation for a regional policy that conforms to EU standards and foresees resolving the problem of delayed development of some regions in an institutional manner. The Council for Equal Development has a mandate to coordinate regional development policy, and a Council for the Development of the Planning Regions has been established as a body responsible for the implementation of the policy in each planning region. The former Agency for Economically Underdeveloped Areas has been transformed into the Regional Development Bureau. Additionally, the National Strategy for 
Sustainable Development and National Strategy for Regional Development (set in 2009) offered possibilities for revitalization of numerous deserted areas in Macedonia. Furthermore, recently revised National Strategy for Tourism Development (covering the period 20112015) gives recommendations for wine tourism development, thus identifying it as a separate strategic cluster.

Furthermore, the opening of EU accession negotiations increased the financial assistance for pre-accession reform being focused on regional development. This was seen as an important part of government policy and a strategically important issue in the EU accession process, which aims to reduce regional differences within the country. As from 2010, the National Program to Promote Regional Development was launched resulting with more than 200 regional development projects being submitted and still in process of implementation. Nevertheless, so far, regional policy has been mainly concerned with economic conditions and with creation of economic infrastructure, while less attention was paid to particular issues concerning wine tourism development.

The Center for development of Vardar Planning region makes efforts for raising awareness and funds for developing wine tourism in the destination. The intention is to combine transit, cultural and wine tourism and create a complex and unique tourism product. The Chambers of Commerce undertake activities for promoting the Macedonian business environment and increasing sales of Macedonian products on the global market, by organizing the event "Producer of wine in the Republic of Macedonia". Despite the efforts by the Macedonian winemakers on establishing a professional wine tasting panel and implementing a program for certification of high quality wines, substantial results are missing. Yet, on highly respected international wine competitions, the Macedonian wines continued to receive international validation for the quality. In the line of initiating activities for organizing wine trails that will be connected into a cohesive product, the "Tikvesh Foundation" was established. Although this foundation tries to collaborate with the Tourism Cluster, the undertaken activities so far, may be assessed as modest due to limited resources. In the frames of the Macedonian Competitiveness Activity Project, a solid base for future development of wine tourism in the destination was set. However, just after project completion, the identified ideas for wine tourism development were not implemented. 
Figure 2. Sector map for destination Wine route

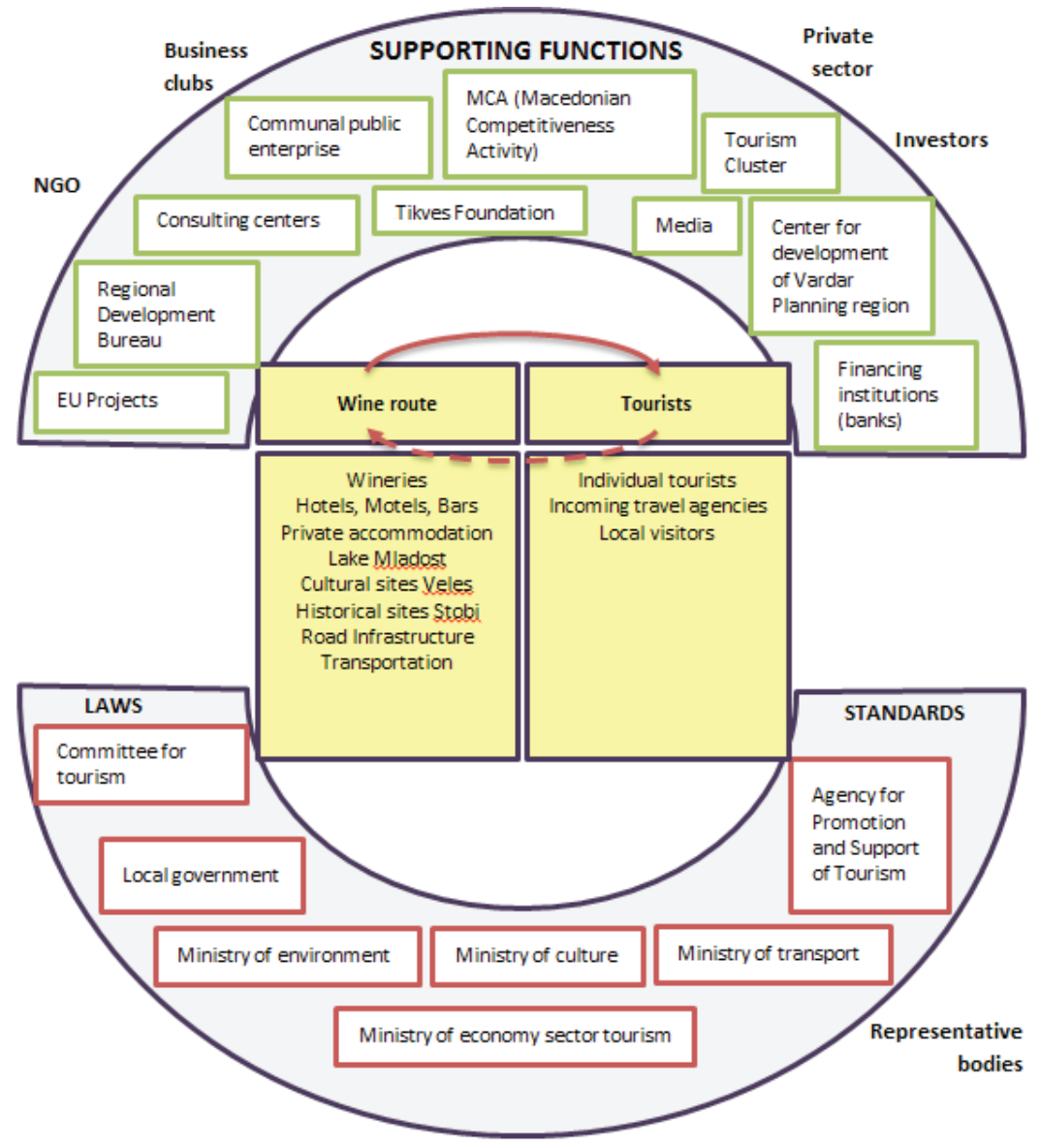

The community involvement in wine tourism development is exceptional. Although being noted in some strategic documents, still the locals are mainly involved in supporting wine tourism only as a potential one. Only small part of the local community is directly or indirectly involved in promotion of wine tourism, generally due to their enthusiasm. Overall, the lack of coordination among the key market players is the general conclusion.

There are many challenges that destination is facing with. The key providers of tourism services within the destination are established networks of supply chain as well as local self-government, NGO sector and Center for development of Vardar planning region.

Applying the Making Markets Work for the Poor (M4P) methodology the sector map for the Wine route is given on Figure 2, which is comprehensive. Many of the supporting functions currently present at the destination may be used in the line of supporting and enhancing sustainable development.

Generally, all tourism activities within the Wine route are driven by the actors at 
regional level. The Center for development of Vardar Planning region makes efforts for raising awareness and funds for developing wine tourism in the destination. The intention is to combine transit, cultural and wine tourism and create a complex and unique tourism product. The Chambers of Commerce undertake activities for promoting the Macedonian business environment and increasing sales of Macedonian products on the global market. "Tikves Foundation" plays crucial role in the line of initiating activities for organizing wine trails that will be connected into a cohesive product. Although this foundation tries to collaborate with the Tourism Cluster, the undertaken activities so far are modest due to limited resources. In the frames of the Macedonian Competitiveness Activity Project a solid base for future development of wine tourism in the destination is set.

\section{Analysis, results and discussion}

In order to evaluate current tourism development of the Wine route, a field survey was undertaken as a part of a broader research conducted during the period 11-19 July, 2014. It included the quantitative approach by introducing a factor analysis. The data were collected by a self-administered questionnaire distributed in the following locations along the Wine route: Demir Kapija, Gradsko, Negotino and Veles. The overall response rate was $85 \%$, while the rest of the questionnaires were incomplete and unusable. It was foreseen to evaluate six previously spotted wineries from the wine region $(75 \%$ of all wineries in the wine region). Yet, during the field research it was detected that the winery "Grkov" was closed due to negative business results, and that the same owner opened a new one (winery "Sato Sobot") in the near vicinity. The winery "Tikves" was excluded from the field survey due to their unwillingness to be a part of the research, so the following wineries were surveyed: "Bovin", "Elenov", "Popova Kula", "Sato Sobot" and "Stobi". According to the working position of the respondents, the structure is $71 \%$ employees, $23 \%$ managers, and $6 \%$ winery owners. Due to fact that the majority of the employees in the wineries are men, the gender structure of the respondents was $88 \%$ male and $12 \%$ female. All respondents were Macedonians with an average age of 38 years.

\section{Supporting functions/services}

Only half of the investigated wineries in the destination have accommodation capacities with an average of 26 rooms per facility. Almost $60 \%$ of the wineries which offer accommodation services do not have a star classification of the facility, although are fully aware that it helps in attracting guests and increases their number. In case of so, it is under a four-star classification providing good quality of accommodation service. The restaurant facilities offer food and beverage services with an average of 122 seats. Besides enjoying the stay and good wine, the visitors may use additional services in the nearby vicinity (Negotino, Kavadarci, Veles or Demir Kapija), like pharmacy, emergency healthcare, a carmechanic, police and fire fighting services. According to the suppliers, the tourist attractions and locations in the destination are easily accessible for tourists, but are not well marked. Yet, there are numerous services that are missing in the supply chain in terms of tourists' satisfaction. The destination is missing regular public buses or van transportation to/from the wineries. There are no public parking plots, public toilets nor public waste disposal. The wine region is missing a tourist information office as well. 


\section{Problems and underlying causes}

The field survey revealed several problems, which could be considered as very large obstacles for tourism development of the Wine route. The average price of the most common service per person that the facilities sell is up to $50 \mathrm{EUR}$, which initiates necessity of improving the services in terms of "better served-better paid". There is an absence of accommodating opportunities within half of the facilities. Domestic tourist agencies and foreign tour-operators are not sufficiently used as intermediaries in the line of increasing the market. Despite the fact that half of the surveyed wineries receive subsidies from the state and thus support their business performance, the access to finance is identified as one of the top-3 limitations to the facilities' development. The second limiting factor refers to the promotion at foreign markets and cooperation with foreign partners. This is another limitation mutually identified by the managers and the employees of the wineries. Yet, a slight difference is noted concerning the third limitation. According to the managers, the economic situation in the country is a strong limiting factor in the facility's development. This is not the case with the employees, who disregarded the economic situation and omit it from the ranking in favor of the specialization at the workplace.

The number of visitors to the facilities in the last two years is very unsatisfactory (3 persons/day in small wineries, and 14 persons/day in large wineries). Only 50-60\% of the visitors are foreign tourists, which leads to very modest multiplier effect. Generally, the foreign tourists come from neighboring countries (Greece, Serbia, Bulgaria, Albania and Kosovo), although there are also foreigners from other European countries and Worldwide. One may find Macedonians from the diaspora as visitors to the destination, as well. Generally, the visitors stay up to 1 day and very rarely 2-3 days. They visit the facilities by car and bus, and exceptionally by train and plane.

The unfavorable economic situation in Macedonia in general, and particularly in this region, leads to law payment in tourism. An interesting note may be underlined concerning the issue that work in tourism is safe and secure. Namely, the male respondents have dilemma where to agree or disagree, while the female employees do not perceive it as safe and secure. According to the working position, the managers of the wineries disagree opposite to one surveyed owner who finds it safe and secure the same as the majority of the employees. This leads to conclusion for having unclear picture referring this issue.

Although unavailability of funding sources, particularly if woman entrepreneur runs it, is detected as an overall obstacle for tourism business, there are slight differences in the perception among different target groups. Namely, while the owners are neutral, the managers agree, and the employees have a dilemma whether to agree or to be neutral. In case when making a gender cross-tabulation, one may note that neither men nor women cannot decide either to be neutral or to agree. On the other side, there is no dilemma for the youth who disagree that this can be an obstacle. Furthermore, closely linked to the previous statement is the one concerning the membership of woman in the Tourism Committee. Namely, the overall perception is that by supporting women's involvement in tourism institution, one may improve the position of women entrepreneurs in tourism. Both genders, agree to strongly agree to this statement, as well as the youth and the employees. Only owners/managers are neutral and are not convinced in the potentially positive reflection concerning this issue. 


\section{Core Value Chain}

The supply side of the destination is consisted of continuous growing number of officially registered wineries (from 54 in 2008, to 81 in 2013). Yet, some of them stopped their production due to negative business results such as the winery "Grkov" from Kavadarci. Today, the following wineries are among the most active within the destination: "Tikves", "Popov" and "Trajkovski" in Kavadarci; "Popova Kula" and "Elenov" in Demir Kapija; "Stobi" - Gradsko; "Bovin" - Negotino and "Sato Sobot" - Veles (opened by the same owner from the winery "Grkov", but at another location). These wineries produce $85 \%$ of total production of Macedonia with different annual production. $5 \%$ of the surveyed wineries produce up to 50,000 liters, $35 \%$ produce up to 75,000 liters, $25 \%$ produce up to $1,300,000$ liters, and $35 \%$ produce up to 7,000,000 liters of wine per year.

The wineries are affiliated in a cluster and make joint offer. The small wineries export abroad up to $40 \%$ of the annual production, while large wineries export up to $70-85 \%$. All wineries that are active within the Wine route region possess working certificate. Some of them are fresh to the market, but some have 10 even 15 years of experience. The smaller wineries have an approximate yearly income up to 50,000 EUR in the last two years, but the larger ones have earned more than 600,000 EUR. The number of employees ranges from few, to over 40 employees and in most cases the employees have secondary education. Half of the investigated wineries receive subsidies from the state, share good opinion on its impacts on the business performance and relatively satisfactory distribution among tourism actors. The facilities use various different marketing channels for promotion of their offer, like: Internet, social networks, print media, TV and radio advertising, billboards, direct communication and sponsorship. Yet, the tourism supply of the Wine route region as a destination is not well promoted via Internet.

The surveyed respondents perceive that the good 'seasons' for destination's development in terms of tourism is summer (due to mobility of tourists transiting the region) and autumn (due to "grape's period"). The utilization of the capacity within the season is estimated to $80-100 \%$, while out of season the wineries work approximately with $20-30 \%$ of the capacity. Being aware of the negative effects of seasonality on tourism business, they take measures and activities for overcoming it, but with modest and limited results.

\section{Conclusion and Recommendations}

Upon detailed field survey and literature review related to the destination's tourism development, it may be concluded that the Wine route region of Povardarie has very modest tourism results. The region is faced by many challenges since the lists of weaknesses and threats for tourism development are long and substantial. Yet, some competitive advantages may be found at quality of services, low service prices, and natural beauties. As a good starting point for further improvement of the destination in tourism manner, one may take in consideration several elements, prioritized to their importance for tourists visiting the destination. So, natural beauties, cultural events, and traditional food are detected as items for enhancing current tourism supply of the Wine route region. Furthermore, being affiliated in a cluster gives a positive light for improvements of the current joint supply with other wineries from the wider region. The worth noticing export data (up to $45 \%$ of the annual production 
for small wineries, and up to $70-85 \%$ for large wineries) presents a solid initial base for strengthening the wine entities in the broader foreign market. The "Tikves Foundation", alongside with the initiatives of the Center for development of Vardar Planning region and the isolated private initiatives, may have crucial role in affirmation of the necessity of introducing wine tourism to the destination in more effective manner.

There is a need to identify measures and activities that will contribute to creating more competitive tourism sector, as well as to enable systematic change in terms of improving tourism services offered in the Wine route region. Namely, there is a necessity of promoting the "wine tourism product" and the region in general to the specific groups of visitors (wine-lovers, adventure-tourists etc.). The solution may be found in the creation of sophisticated software modules for wine tourism promotion. Furthermore, the market players should contribute much more in terms of coordinating the wine tourism activities. In this line, improvement of tourism competitiveness may be found in strengthening the coordination with local government, cooperation with foreign partners, presence of political will as well as raising awareness of local inhabitants concerning the positive effects of wine tourism development.

The vision of change for services perceives interventions in more systematic approach. In this line, the priority strategic action is seen in improving the knowledge and behavior of employees in tourism sector of the region. Despite the overall unfavorable economic situation in the country and the low payments in tourism, one may create an environment for stabile and high performance employment. Developed complex and unique "wine tourism product" is the final vision of change perceived for the Wine route region.

\section{References}

Babu, S. S., Mishra, S. \& Parida, B. B. (2008). Tourism development revisited: concepts, issues and paradigms. Saga.

Constantin, D. (2000). Tourism and Environmentally Sustainable Regional Development: The Case of Romania. Conference Proceedings, 40th Congress of the European Regional Science Association, 29 August-1 Sept 2000.

Crouch, G. I. \& Ritchie, B. J. R. (1999). Tourism, competitiveness and societal prosperity. Journal of Business Research, 44(3), 137-152.

Dimoska, T. \& Petrevska, B. (2012). Indicators for Sustainable Tourism Development in Macedonia. Conference Proceedings, First International Conference on Business, Economics and Finance "From Liberalization to Globalization: Challenges in the Changing World", 13-15 September, 2012, Stip, Macedonia, 389-400.

d'Hauteserre, A. (2000). Lessons in managed destinations competitiveness: the case of Foxwoods Casino Resort. Tourism Management, 21, 23-32.

Dwyer, L \& Kim, C. (2003). Destination competitiveness: determinants and indicators. Current Issues in Tourism, 6(5), 369-414.

Enright, J. M. \& Newton, J. (2004). Tourism destination competitiveness: a quantitative approach. Tourism Management, 25, 777-788.

Giaoutzi, M. \& Nijkamp, P. (2006). Tourism and regional development - new pathways. Ashgate Publishing, Ltd. 
Gooroochurn, N. \& Sugiyarto, G. (2004). Measuring competitiveness in the travel and tourism industry. Discussion paper TTRI. Nottingham University Business School, Nottingham.

Huybers, T. (2007). Tourism and developing countries. Edward Elgar Publishing.

Johns, N. \& Mattsson, J. (2005). Destination development through entrepreneurship: a comparison of two cases. Tourism Management, 26, 605-616.

Kozak, M. \& Remmington, M. (1999). Measuring tourist destination competitiveness: conceptual considerations and empirical findings. Hospitality Management, 18, 273-283.

Maliàn-Gonzàlez, A. \& Garzìa-Falcòn, M. (2003). Competitive potential of tourism in destinations. Annals of Tourism Research, 30(3), 720-740.

Pearce, D. \& Butler, R. (2002). Contemporary issues in tourism development. Routlege.

Petrevska, B. \& Nestoroska, I. (2015). Economics of Tourism: Recent Developments in Macedonia, LAMBERT Academic Publishing.

Petrevska, B. (2012). Tourism contribution to regional development: best practice in Macedonia. Journal of Community Positive Practices, 12(3/2012), 425-440.

Petrevska, B. \& Manasieva Gerasimova, V. (2012). Tourism in Regional Development: Empirical Evidence. Innovative Issues and Approaches in Social Sciences, 5(2), 6-20.

Ramos, A. D. \& Jimènez, P. S. (2008). Tourism development: economics, management and strategy. Nova Science Pub.

Raina, A. K. \& Agarwal, S. K. (2004). The essence of tourism development: dynamics, philosophy and strategies. Sarup \& Sons.

Rayan, T. (2010). Tourism development. Lambert Academic Publishing.

Sharma, K. K. (2004). Tourism and regional development. Sarup \& Sons.

Sharpley, R. \& Telfer, D. J. (2002). Tourism and development: concepts and issues. Channel View Publications.

Stabler, M., Papatheodorou, A. \& Sinclair, T. M. (2010). The economics of tourism. Taylor \& Francis.

State Statistical Office of the Republic of Macedonia (2014a). Regions of the Republic of Macedonia 2014. Skopje.

State Statistical Office of the Republic of Macedonia (2014b). Macedonia in numbers. Skopje.

State Statistical Office of the Republic of Macedonia (2014c). Women and men in the Republic of Macedonia. Skopje.

Telfer, D. J. \& Sharpley, R. (2008). Tourism and development in the developing world. Taylor \& Francis.

Ul Haque, I. (1995). Trade, technology, and international competitiveness. The World Bank, Washington.

Barbosa, L. G. M. (2008). Measuring destination competitiveness: The Brazilian model. Enzo Paci papers, 6, 397-425. 